DOI 10.18551/rjoas.2019-01.01

\title{
MODEL OF ENTREPRENEURSHIP SPIRIT IN MILLENNIAL GENERATION
}

\author{
Wahyuningsih Erna \\ Faculty of Economics and Bussiness, Perbanas Insitutute, Indonesia \\ E-mail: rizal.mawardi@perbanas.id
}

\begin{abstract}
ABSTACT
This study aims to know and analyze the influence of environment, lifestyle and the role of social media to the spirit of entrepreneurship in the Millenial Generation. This type of research based on eskplanasi level is in the form of associative research that aims to determine how the relationship between variables with Purposive Sampling technique is the respondent chosen intentionally with certain characteristics that are believed and representative of the population. The unit of analysis in this study is Millenial Generation aged between 17 years to 38 years. This research was conducted in Jakarta, Bogor, Tangerag and Bekasi areas. The study was conducted in January 2018 - May 2018. The population in this study is Millenial Generation also known as Generation $Y$ is demographic group after Generation X (Gen-X), Sampling 100 consideration is sufficient to be distributed to Jabodetabek area. In this study, the independent variables are environment variable $(X 1)$, lifestyle $(X 2)$, and social media role (X3) while the dependent variable is the entrepreneurship spirit $(Y)$ with 65 indicators as primary data source. The result of this research is partial regression coefficient for environment variable of result of prob. $t$ arithmetic of environment free variable equal to 0,036 smaller than 0,05 so that free environment variable have significant influence but result t-hitung $(-2,126)$. Result of negative or unidirectional value of environment variable to bound variable Entrepreneurship Spirit mean Environment influences negatively to Entrepreneurship Spirit. While the influence of free variable of Lifestyle to the dependent variable of Entrepreneurship Spirit, the probability $t$ value $(0.000)$ is smaller than $0.05 \mathrm{t}$-count 4,898 so it can be said that the free variable Lifestyle has significant influence, so also the influence of free variable of Social Media to dependent variable Entrepreneurship spirit, the value of prob t arithmetic (0.002) is smaller than 0.05 t-count 3.253 so it can be said that the free variable Social Media significantly influence the bound variables Entrepreneurship Spirit. In the $F$ test test the prob value. $F$ count (sig) in the value table is 0,000 smaller than the 0.05 significance level so it can be concluded that the distributed linear regression model is feasible to be used to explain the influence of Environment, Lifestyle and Social Media on Entrepreneurship spirit with $\mathrm{F}$ test result 24,993 $>3,61$. Linear Regression $Y=28,710+(-0.203) X 1+(0,454) X 2+(0,364) X 3+e$., the equation informs the most influential variable to Entrepreneurship Spirit is the Social Media Role variable with standardized coeftsients 0,454 larger than the variable of Environment and Lifestyle. The result of coefficient test of determination shown by $\mathrm{R}$ square is $43,9 \%$ while the rest $56,1 \%$ is influenced by other factors not discussed in this research.
\end{abstract}

\section{KEY WORDS}

Environment, liefestyle, role of social media, entrepreneurship spirit.

The Millennial Generation is the terminology of the generation that is currently being discussed by many in the world in various fields, what and who is the millennial generation? Millennials (also known as Millennial Generation or Generation Y) are demographic groups (cohorts) after Generation X. Social researchers often classify generations born between the 1980 s and 2000s as the millennial generation. So it can be said that the millennial generation is the current generation of young people aged around 17-38 years.

Studies of millennial generations in the world, especially in America, have been carried out, including a study conducted by the Boston Consulting Group (BCG) with the University of Berkley in 2011 with the theme of American Millennials: Deciphering the Enigma 
Generation. The previous year, 2010, the Pew Research Center also released a research report entitled Millennials: A Portrait of Generation Next.

In Indonesia, studies and studies on the millennial generation have not been widely implemented, even though the population of Indonesia aged between 17-38 years is currently very large, $34.45 \%$. Last year there was indeed a business magazine whose main headline was discussing the millennial generation, but unfortunately its coverage was still limited to the millennial generation with the world of marketing, it had not entered into the scope of their lives as a whole.

Compared to the previous generation, the millennial generation is unique, the results of research released by the Pew Researh Center for example clearly explain the uniqueness of the millennial generation compared to previous generations is a matter of using technology and pop / music culture. The life of the millennial generation cannot be separated from technology, especially the internet, entertainment / entertainment has become a basic necessity for this generation. The phenomenon of the low interest and motivation of the younger generation for entrepreneurship is now a serious thought for the community, especially the workforce, the government does not remain silent and the world of education is looking for the right formulation to be synergized with industrial needs. But what happens between college graduates and the willingness of unbalanced employment opportunities, the world of education, and society striving to foster an entrepreneurial spirit, especially changing the mindset of young people who have only been interested as job seekers when they finish school or college. This is a challenge for schools and universities as graduates producing institutions. (Scientific Journal Business and Entrepreneurship Forum STIE MDP, Vol. 1 No. 2 March 2012, p. 113) Education, Employment, and Entrepreneurship, Education, Work, and Entrepreneurship The most important issue faced by youth from the past until now is the issue of education and employment, because these two things are the most influential and determine their future. Their level of success in adulthood and old age is determined by the education and work they receive in the future. Besides being young, entrepreneurship has now become an alternative for young people in their work, business start-ups have sprung up in various cities. Once graduated they no longer hunt for job vacancies, but try to find business opportunities and make the business opportunity an entry point to organize their lives.

The lifestyles of young people who tend to be hedonists, especially in big cities have become public secrets, they have their own ways to vent their expression, their world of life can not be separated from entertainment and technology, especially the internet. What is the lifestyle of Indonesian youth ?, What are the hobbies and sports that young people like ?, What are the habits and behavior of youth towards technology, especially the internet? And what is the interaction of youth on social media? Is a question that needs to be answered regarding the relationship of the lifestyle of young people.

Finally, by fully understanding the portrait of the millennial generation in Indonesia, we have an overview of their views, aspirations and perspectives on all aspects of their lives, so that Indonesian human development as a whole can be right on target, because at the end of this millennial generation the fate and future of the nation and country. Humans during their lives will always get influence from family, school, and the wider community. The family environment is the first and foremost educational environment for humans to provide guidance and examples for humans. Therefore the family environment has a very important role in the effort to develop personality. In the family environment is the place for the formation of character and attitude to determine its future.

Gunarsa (2009: 5) that the family environment is "the first environment that has a profound influence first, from family members (father, mother and siblings) to obtain all basic abilities, both intellectual and social. Every attitude, view, and opinion of parents or other family members will be an example in behaving. In this case the family environment as the first educational environment is very important in forming a fundamental personality pattern. Because in the family first gets knowledge about values and norms.

Lifestyle is only one way to group people according to their psycho-graphic pleasures. Lifestyle is in principle how a person spends his time and money. There are people who like 
to seek entertainment with their friends, there are those who like to be alone, some are traveling with family, shopping, doing dynamic activities, and some who have free time and money for socio-religious activities. Lifestyle has something to do with the role of social media which has become increasingly prevalent lately and has made topics at various needs, clearly the role of social media in creating the creativity of the young generation is very important.

The role of social media today is growing rapidly in the social life of the Indonesian people, including all elements of society, old, young, students or youth all feeling the touch of social media. Social media users for adolescents are just as big, with 23.8 million people or $18 \%$ percent of Indonesia's population, this proves that social media takes a role in shaping the character of the younger generation, plus the significant impact seen from the side positive or negative. The positive impact that we can see from using the internet or social media for the younger generation is that they can learn to improve and develop technical skills and social relations that are really needed in today's digital age. Consciously or unconsciously, social media takes a role in shaping the character of the younger generation itself, with the impact that is caused indirectly contributing significantly to the behavior of the people who use it, for that in using social media we must be intelligent, intelligent in the meaning of understanding what we should do in using it, in order to create a smart and competent generation in managing information media as a database in gaining knowledge. And social media should be present as a spot education in this case as a place or place to learn to manage the flow of modernization in the form of technology, information and communication, so that the younger generation of Indonesia appears as a smart generation in all fields, and smarter in using social media.

From the background of the problems that have been described, the author wants to examine with the title: The Effect of Environment, Lifestyle and Social Media on the Spirit of Entrepreneurship in the Millennial Generation.

Based on the background that has been stated, in the research of the Millennial Generation it can be stated that the formulation of the problem is whether the environment, lifestyle and the role of social media will positively influence the spirit of entrepreneurship in the millennial generation. While the purpose of the research is to find out and analyze the influence of the Environment, Lifestyle and the Role of Social Media on the Entrepreneurship Spirit in the Millennial Generation.

\section{LITERATURE REVIEW}

The rapid development of time makes people have many needs. To fulfill all these needs, many ways are carried out from producing products needed by the community to how to distribute a product to consumers through marketing activities. Business people must have expertise in marketing their products. This makes a challenge done by business people or entrapreneurs.

Hendro, $(2011,29)$ explained that Entrepreneurship carries out a process called creative destruction to produce added value in order to produce higher values. For this reason, entrepreneurial skills are based on creativity. Therefore, it can be said that the core of entrepreneurial skill creativity.

Many argue that entrepreneurship is a business activity that has knowledge, skills and art. According to Lambing and Charles Kuehl in the Entrepreneurship book (1999), entrepreneurship is a creative endeavor that builds a value that does not yet exist to become available and can be enjoyed by many people. Every successful entrepreneur has four basic measures, namely:

- Ability (relationship with IQ and Skill), a) reading opportunities, b) innovating, c) managing and d) selling;

- Courage (relationship with EQ and mental), a) overcoming fear, b) Controlling risk and c) getting out of the comfort zone;

- Perseverance (relationship with self motivation), a) persistence / resilience, unyielding, b) determination / firmness in his beliefs and c) strength of mind. 
Entrepreneurship is a knowledge that is the result of field testing, collected, researched and assembled as a source of information that is useful for others who need it so that entrepreneurship can be incorporated into scientific disciplines, both theoretical and empirical (the results of field tests).

While the art of finding ideas, inspiration and business opportunities requires imagination, visualization and thinking that sometimes must be contrary to logic. Think differently to find brilliant ideas. All of that requires creativity, truly new innovations so that the elements and the power of art to find ideas in how to overcome difficulties, control human resources (HR) and customers have a considerable role. Therefore the influence of the power of art in the science of entrepreneurship is very large. Like a samurai without martial arts, it will be difficult to win. Until when a person becomes proficient, a predicate will emerge as a form of profession. Entrepreneurship is a profession, a life choice that must be done professionally (in the sense of being honest, open, committed, consistent, right in promises, responsibility, understanding the limits of his rights, understanding professional ethics and discipline). Everything can be done because entrepreneurs need intuition or reasoning power in carrying out their business and all of that can be obtained because basically humans are given sensitivity in thinking.

Entrepreneurship spirit. Initially entrepreneurship was defined simply. In ancient times people often decided to go to a different place in order to conduct an exchange or trade which is commonly called a go-between (Robert. Entrepreneurship. Edition 6. Boston: McGraw Hill). He made an agreement on a work contract at the request of an item, at that time sprinkled with someone who would exchange the buyer with a sum of money for his labor. The beginning of entrepreneurship is a contractor, namely a person who makes a work contract agreement on a number of jobs previously determined by compensation for a sum of money whose risks are borne by the recipient of the contract. Therefore, entrepreneurship in the past was called the risk taker (risk taker).

In the era of entrepreneurship industry, people are brave enough to take risks and do not have capital which is always measured by money which deals with capital owners to work on certain projects on their resources but do not have sufficient knowledge. Those who dare to take risks in their time are referred to as joint venture capital-based entrepreneurship (one side is intellectual capital, the other is equety capital). In this century which is the backbone of success in a business is the creativity of an entrepreneur itself (Creativepreneur)

Alex S. Niti Semito defines Spirit as doing work more actively so that work will be expected to be faster and better. Entrepreneurial work is strongly influenced by several factors, including: (1) Business or business opportunities, (2) Interest in business or business (3) Capital, whether it is available, (4) Clarity, whether from family, friends who have worked same effort. Other factors that can influence entrepreneurial morale include factors such as family support, family, friends, business experience, economic conditions, employment conditions, and available resources. Furthermore, there are still other factors that can influence the entrepreneurial work spirit, namely the consideration between experience with spirit, energy, and optimism in the success of a business or business.

Environment Life Place. Understanding the environment based on law and according to experts. in general, the definition of the environment is a system of life where there are cmpur of human hands to the order of the ecosystem. The understanding of the environment according to the limitations of law No. 4/1982 is a system that is a unity of space with all objects, power, circumstances, and living things including humans and their behavior which determines the lives and welfare of humans and other living beings.

According to Prof. DR. Ir. Otto Soemarwoto, Environment is the number of all objects and conditions that exist in the space we occupy that affect our lives. There is also according to Emil Salim, Environment is all objects, conditions, conditions and influences that are contained in the room that we occupy and affect living things including human life.

In general, the environment is everything that exists around the object and can affect or influence the subject. Thus the entrepreneurial environment is everything that is around entrepreneurship and can influence and be influenced by entrepreneurs. In the context of 
efforts to create new entrepreneurs and develop existing entrepreneurs, what is meant by environment is an external environment consisting of customers, suppliers, competitors, creditors, economics, social, political, technological, and ecological. But not all of these external environments have the same significance in influencing the birth and development of entrepreneurs.

The birth of a new business starts from someone's intention or interest to start a business. When someone has the intention to start a new business, it needs to be supported by an environment that can encourage that interest to become a reality. From various entrepreneurial environments that influence, not all environments provide support at the same level in realizing ideas and intentions of entrepreneurship into reality. Therefore it is necessary to analyze entrepreneurial environmental factors that support the growth of entrepreneurship, so that an optimal entrepreneurial environment condition can be developed to support entrepreneurial growth. (Sri Haryani, YKPN Yogyakarta)

Bygrave (2004) states that internal factors that can trigger the birth of entrepreneurship consist of achievement, locus of control, tolerance, risk taking, personal values, education and experience. The birth of entrepreneurship is also triggered by external factors such as opportunities, the existence of successful entrepreneurs / role models, resources, incubators, government policies, competitors, customers, suppliers, and investors / banks.

Entrepreneurship operates in a dynamic environment, which generally cannot be controlled by the entrepreneur itself. The entrepreneurial environment itself is very broad, so the research carried out by previous researchers also varied widely. The entrepreneurial environment literature generally addresses the entrepreneurial environment which includes the legal and institutional framework, the presence of experienced entrepreneurs, the presence of skilled workforce, supplier accessibility, customer accessibility or new markets, the level of competition between companies, government policies that support, provision of training and service support and infrastructure. In addition, the characteristics of people, skills, experience, and motivation, play an important role in the creation of new businesses

Increasing the effectiveness of entrepreneurship development programs requires broad support from all existing community structures and organizations. Research Haryani (2013) shows that the environment has a positive effect on entrepreneurial intentions, where parents and relatives can help prospective entrepreneurs in building networks, needed financial assistance, and moral support. Thus with the study of Crissanti and Tjiptono (2012), it shows that instrumental readiness such as access to sources of capital, access to information, and social networks have a positive effect on entrepreneurial intentions.

\section{Understanding of Lifestyle}

Lifestyle is broadly defined as a way of life that is identified by how someone spends their time (activities), what they consider important in their environment (interests), and what they think about themselves and also the world around them (opinion). The lifestyle of a society will be different from other communities. Even from time to time the lifestyle of an individual and certain groups of people will move dynamically. Lifestyle is basically a behavior that reflects what problems actually exist in the minds of customers who tend to mingle with various things related to emotional and psychological problems of consumers. 1 Lifestyle is a concept that is more contemporary, more comprehensive, and more useful than personality. For this reason, great attention must be paid to efforts to understand concepts or words called Lifestyle, how life styles are measured, and how lifestyles are used. Lifestyle is defined as a pattern in which people live and spend time and money. Lifestyle viewed from marketing is a function of consumer motivation and prior learning, social class, demography, and other variables. Lifestyle is a summary conception that reflects consumer value.2 1 Nugroho J. Setiadi. Consumer Behavior, Kencana, Jakarta, 2010, p. 77-79. 2 James F. Engel, et. al., Consumer Behavior, Binarupa Aksara, Jakarta, Volume 1, 1994, Lifestyle can influence one's behavior, and ultimately determine one's consumption choices. Lifestyle according to Kotler (2009: 192) Lifestyle is a person's lifestyle in the world that is expressed in activities, interests, and opinions. Lifestyle describes "the whole person" in interacting with their environment. Lifestyle describes the whole pattern of someone in action and interaction in the world. 
According to Assael (2007: 89) lifestyle is "A fashion of living that is identified by people spending their activities, what they consider important in their environment, and what they think of themselves and the world around them (opinions) ". In general it can be interpreted as a lifestyle that is recognized by how people spend their time (activities), what is important for people to consider in the environment (interests), and what people think about themselves and the world around (opinion).

Whereas according to Minor and Mowen (2008: 282), lifestyle is showing how people live, how to spend money, and how to allocate time. So that it can be concluded that lifestyle is a pattern of someone who is expressed in activities, interests and behavior in spending money and how to allocate time. The main factors forming the lifestyle can be divided into two, namely demographically and psychographically. Demographic factors for example are based on education level, age, income level and gender, while psychographic factors are more complex because of the constituent indicators of consumer characteristics.

The concept of lifestyle when used by marketers carefully, will be able to help to understand the changing consumer values and how these values affect consumer behavior. Lifestyle changes have implications for changing tastes (different tastes of men and women), habits and behavior.

Nugrahani (2007: 176) adds that: lifestyle is a combination of self-expression needs and group expectations of a person in acting based on prevailing norms. Therefore many types of lifestyles that develop in society are now known for example hedonic lifestyles, lifestyles metropolis, global lifestyle and so on.

Whereas Nugroho (2006: 124) put forward the thoughts above, and based on lifestyle is the way of life of individuals identified by how people spend their time (activity), what they consider important in their lives (interests) and what they think about the world around it. Whereas Nugroho (2006: 124) suggests the above, lifestyle is the way of life of individuals identified by how people spend their time (activities), what they consider important in their lives (interests) and what they think about the world around them. Other experts Alwisol (2005: 97) suggest that Lifestyle is everyone who has a goal, feels inferior, struggles to be superior. But everyone tries to realize that desire with a different lifestyle. Adaler states that lifestyle is a unique way of each person in struggling to achieve a specific goal that has been determined by the person in particular life where he is. There are four (4) things and understand the lifestyle that relates to consumers in preparing entrepreneurial activities:

- Marketers can use consumer lifestyles to segment target markets. So that what is desired to open a business is in accordance with the target market;

- Understanding of consumer lifestyles will also help in positioning products on the market using advertising. Which is in accordance with the style of young people now and advertisements indicate the form of edutaimen means that advertisements are presented in an entertaining way;

- If lifestyle is known, marketers can place their ads on media that are most suitable for young people;

- Knowing the lifestyle of consumers means marketers can develop products according to the demands of their lifestyle.

Starting from the understanding that begins marketing activities will open the mind of business beginners reading opportunities that can be entered. The current generation has relied on technology; the development of this technology also seems to make it easier in various fields, especially in the field of telecommunications which is often referred to as a gadget. Already many have found very interesting gadgets from smartphones, tablets and laptops, with the facilities available on the gadget. Gadget users can find lots of alternatives and the choice of information they need. The process of consumption and use of technology continuously, over time will form a pattern of behavior that becomes a lifestyle. Where lifestyle is a pattern of one's life in the world expressed in activities, interests, and opinions. The increasing activity of young people from time to time makes their lifestyle change, with the existence of these activity gadgets easier to overcome, gadgets indirectly get involved in lifestyle changes in the millennial generation. As stated by philosopher Baudrillard, today's human lifestyle is shaped by imagination factories such as fashion, computers, so 
researchers want to describe how generations in their activities, interests or opinions take advantage of technological developments in order to foster an entrepreneurial spirit as an alternative to pursuing careers.

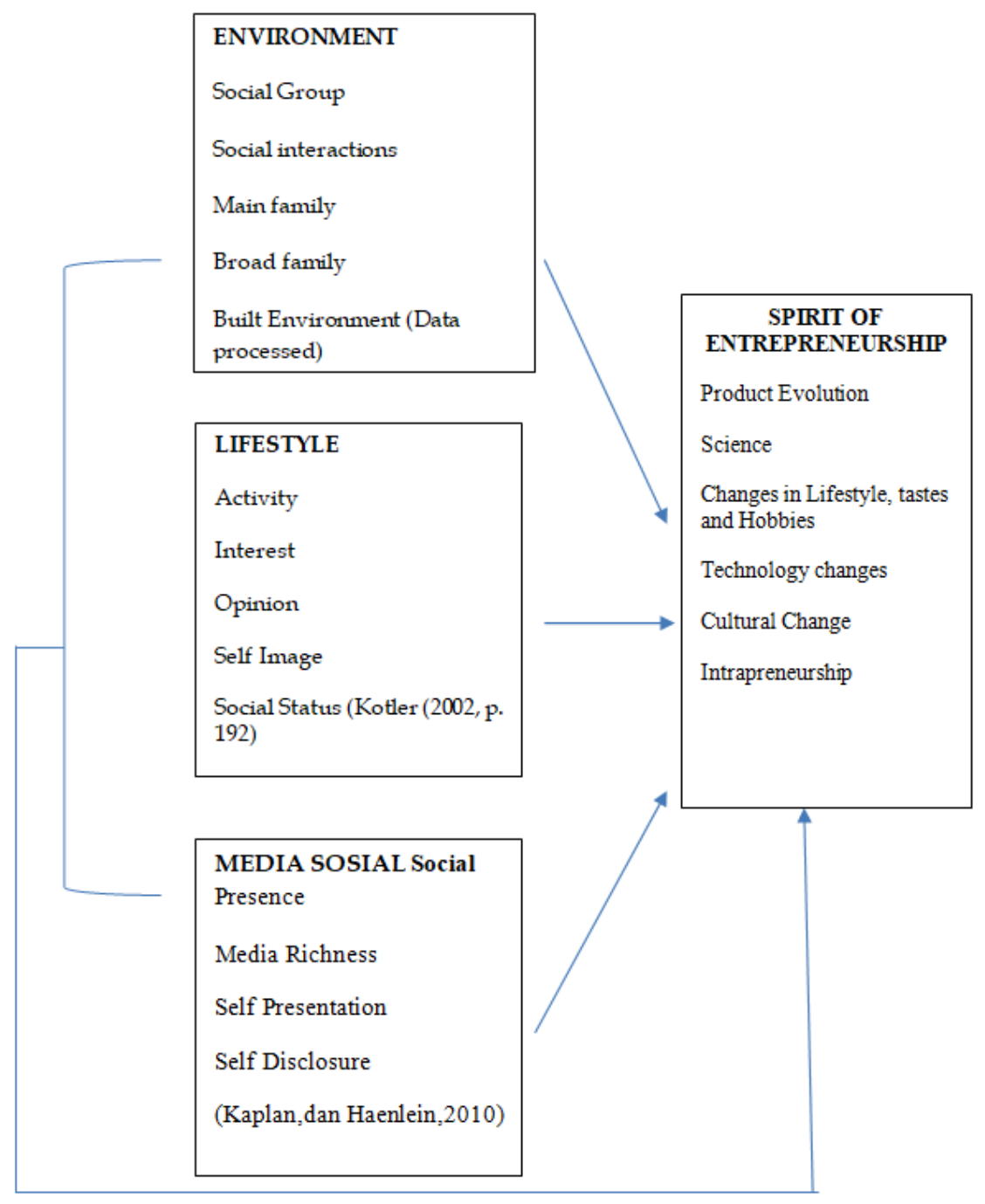

Figure 1 - Research Framework

Social Media. Social networking sites allow users to connect by creating personal profile information and invite friends and colleagues to access profiles and to send e-mails and instant messages. Profiles generally include photos, videos, audio files, blogs and so on. Examples of social networking sites are Facebook, MySpace, and Google+. The use of communication media facilities today has developed so rapidly along with the advancement of communication technology, where living in an environment is faced with many choices to be able to convey / access information through conventional media such as print and electronic media and the most developed is social media. Definition of social media is an online media, where users can easily participate, share and create content including blogs, social networks (Facebook, Youtube, Myspace and Twitter), wikis, forums and the virtual world. In the use of social media the most frequently used by people is social networking, because this site allows people to create personal web pages, which can connect with friends to share information and communicate. Of the many social networks, the use of Facebook and Twitter is the most loved by people because it is more practical, economical and inexpensive to use. Simply having a smartphone can already access information anytime and anywhere through social media, and the most interesting because it can convey information related to our activities, both personal and group. Actually the benefits or role of 
social media as a driver of advancement of entrepreneurship, one of which is widely used as a media campaign. It is very easy and inexpensive to use social media for promotion, Facebook as an example. Among young people surely know Facebook, in Indonesia the users have reached millions of people and can be used in addition to communication as well as being a field of creativity to develop business, then an entrepreneurial spirit arises. Business beginners can take advantage of opportunities to promote small businesses to the community, or just introduce their creative products. With one write and enter all Facebook users in the world who have become friends, we can see the posts that contain the promotion. try the product from you. And we need to remember that being a successful entrepreneur is not an easy thing. The key is hard and patient effort. With the presence of social media which tends to facilitate work, it should be able to optimize the role of Social Media as a means to develop business.

Hypothesis:

$\mathrm{H} 1$ : there is the influence of environment on the Entrepreneurship Spirit on the Millennial generation;

$\mathrm{H} 2$ : There is the influence of Lifestyle on the Entrepreneurship Spirit in the Millennials;

H3: there is the influence of Social Media on the Entrepreneurship Spirit in the Millennials;

$\mathrm{H} 4$ : there is the influence of the Environment, Lifestyle and Social Media on the Spirit of Entrepreneurship in the Millennial Generation.

\section{METHODS OF RESEARCH}

This type of research based on eskplanasi level is in the form of associative research that aims to determine how the relationship between variables (Sugiyono, 2012). According to Juliandi (2013: 56) research in associative problems is research that seeks to examine and explain how an independent variable affects the dependent variable. In this study the Independent variable is the Environment variable (X1), Lifestyle (X2), and Social Media (X3) while the dependent variable is the Entrepreneurship Spirit variable $(Y)$.

To find out the work process in the study in detail as follows:

Table 1 - Research design

\begin{tabular}{|c|c|}
\hline $\begin{array}{l}\text { Types of research: } \\
\text { Description with a quantitative approach }\end{array}$ & $\begin{array}{l}\text { Relations between Variables: } \\
\text { X1: (Environment) } \\
\text { X2: (Lifestyle) } \\
\text { X3: (Social Media } \\
\text { Y: (Entrepreneurship spirit) }\end{array}$ \\
\hline $\begin{array}{l}\text { Research Scope: } \\
\text { The Jakarta and surrounding communities } \\
\text { include Bogor, Depok, Tangerang, and Bekasi }\end{array}$ & $\begin{array}{l}\text { The intended respondent: } \\
\text { Women and Men aged between } 17-28 \text { years in } 2018 \text { or who } \\
\text { are often categorized as Mellenial or Generation Y generations }\end{array}$ \\
\hline $\begin{array}{l}\text { Population: } \\
\text { Millennial Generation } \\
\text { Sample: } \\
100 \text { people }\end{array}$ & $\begin{array}{l}\text { Data source: } \\
\text { Primary }\end{array}$ \\
\hline $\begin{array}{l}\text { Method of collecting data: } \\
\text { Questionnaire and Literature }\end{array}$ & $\begin{array}{l}\text { For Data Analysis: } \\
\text { SPSS } 19\end{array}$ \\
\hline Validity and Reliability Testing & Uji Asumsi Klasik, terdiri dari: \\
\hline Test. Normality & Autocorrelation Test \\
\hline Test for heterocedasticity & Multicollinearity Test \\
\hline $\begin{array}{l}\text { Data analysis: } \\
\text { Multiple Linear Analysis }\end{array}$ & Coefficient of determination \\
\hline $\begin{array}{l}\text { Hypothesis testing } \\
\text { (Using the SPSS Computer Program) }\end{array}$ & Result \\
\hline
\end{tabular}

Multiple Linear Regression Analysis. Multiple regression analysis aims to measure the strength of the relationship between two or more variables, also shows the magnitude of the influence between the independent variables and the dependent variable (Ghozali, 2011). 
Multiple linear regression analysis carried out in the study using the model method as follows:

$$
Y=\alpha+\beta 1 X 1+\beta 2 X 2+\beta 3 X 3+e
$$

Where: Y: Entrepreneurial spirit, $\alpha$ : Constants coefficient, $\beta 1-\beta 2 \beta 3$ : Regression coefficient, $Y$ : Entrepreneurship spirit, $X 1$ location, $X 2$, lifestyle and $X 3$. The role of social media, $\mathrm{e}=$ annoying variance.

\section{RESULTS AND DISCUSSION}

Analysis of Multiple Linear Regression. The calculation of multiple linear regressions between environmental quality, lifestyle and the role of social media on the entrepreneurial spirit with the help of the SPSS version 19 program in the calculation process can be obtained as follows:

$$
Y=28,710+(-0,203) X 1+(0,454) X 2+(0,364) X 3+e
$$

The results of multiple linear regression equations give the understanding that:

- $\quad \beta 1$ (environmental regression coefficient) is negative, meaning if the environment decreases the entrepreneurial spirit for the Millennial generation increases;

- $\quad \beta 2$ (lifestyle regression coefficient value) is positive, meaning that if the lifestyle increases, then the entrepreneurial spirit also increases experienced by the Millennial generation;

- $\quad \beta 3$ (regression coefficient value of the role of social media) is positive, meaning that if the role of social media is increasing, then the entrepreneurial spirit experienced by the Millennial generation is also increasing.

$R$ value is 0.662 , this means that the relationship or correlation between the factors that influence the entrepreneurial spirit is strong because $>0.50$. The $R$ Square value is 0.439 or $43.9 \%$, this indicates that the entrepreneurial spirit variable that can be explained by environmental variables, lifestyle and social media role is $43.9 \%$, and while the remaining 56.1 is explained by other factors not included in the model this research.

F-Test. This test was conducted to determine whether the environment, lifestyle and the role of social media influence the entrepreneurial spirit.

The calculated $F$ value with a significance level of 0,000 ) below 0.05 ) is 24,993 . Based on the level of significance, it is concluded that $\mathrm{Ho}$ is rejected and $\mathrm{H} 1$ is accepted. This means that the independent variables consisting of Environment, Lifestyle and the Role of Social Media can be used to measure the Entrepreneurship Spirit variable or it can be interpreted as a feasible research model.

Hypothesis testing. This test was conducted to determine whether the environment, lifestyle and the role of social media influence the entrepreneurial spirit. that:

Based on the calculation of multiple regression tests, the results give the understanding

- Environmental influence on entrepreneurial spirit, based on calculation of table 4, the regression coefficient value is positive and the significance value for the environment is $a=0.036<0.05$ indicating that the environment has a significant influence on the entrepreneurial spirit;

- The influence of lifestyle on the entrepreneurial spirit of the calculation of table 4, obtained a positive regression coefficient and a significance value for lifestyle is $a=$ $0,000<0.05$ indicating that lifestyle has a significant influence on the entrepreneurial spirit;

- The Influence of Social Media Roles on entrepreneurial spirit, the results of calculation of table 4 , obtained a positive regression coefficient and a significance value for the role of social media is $a=0.002<0.05$ indicating that the role of social media has a significant influence on the entrepreneurial spirit. 


\section{DISCUSSION OF RESULTS}

Environmental influences on the spirit of entrepreneurship. The negative value results in the Environment variable or not in the direction of the Entrepreneurship Spirit dependent variable means that the environment influences the Entrepreneurship Spirit but is not in the same direction that the environment is not influential to form Entrepreneurship Spirit, prob value (0.036) is less than 0.05 . The regression coefficient for the Environmental variable of 262 is negative, meaning that the environment has a significant effect on the direction of negative influence on the Entrepreneurship Spirit because the Spirit of Entrepreneurship does not depend on how the external environment becomes a spirit of Entrepreneurship. The current generation is having strong thoughts and beliefs that can build their future because of how they can explore their potential from within themselves.

The Influence of Lifestyle on the Spirit of Entrepreneurship. The influence of Lifestyle independent variables on the dependent variable of Entrepreneurship Spirit, the value of prob $t$ count $(0,000)$ is smaller than $0.05 \mathrm{t}$ count 4,898 so that it can be said that the independent variable of Lifestyle has a significant effect. Lifestyle regression coefficient is positive and most dominant compared to the Social Media variables studied. This means that the Millennial Generation Lifestyle increasingly characterizes the generation that adapts to technology so quickly that the opportunity to create in developing itself in its own way and easily adjusting values in its era with prestige makes the dignity and dignity that people always see.

Effect of the Role of Social Media on Entrepreneurship Spirit. The Influence of the independent variables of the Role of Social Media on the dependent variable of Entrepreneurship Spirit, the value of prob t count (0.002) is smaller than $0.05 \mathrm{t}$-count 3.253 so that it can be said that the Social Media independent variable has a significant effect on the variable tied to Entrepreneurship Spirit. The Social Media regression coefficient is positive, meaning that social media influences the Spirit of Entrepreneurship because the Role of Social Media makes it a means for Millennials to develop themselves by utilizing business opportunities through social media.

Effect of Environment, Lifestyle and the Role of Social Media on Entrepreneurship Spirit. In the F-test the prob value. F count (sig) in the value table 0,000 is smaller than the significance level of 0.05 so that it can be concluded that the linear regression model that is properly distributed is used to explain the influence of Environment, Lifestyle and Social Media on the spirit of Entrepreneurship., 61.

Linear Regression $Y=28,710+(-0,203) X 1+(0,454) X 2+(0,364) X 3+$ e., the equation informs that the most influential variable on Entrepreneurship Spirit is the variable of Social Media Role with standardized coeftsients of 0.454 greater than the Environment and Lifestyle variables. The results of the determination coefficient tests are indicated by $R$ square of $43.9 \%$ while the remaining $56.1 \%$ is influenced by other factors not discussed in this study.

\section{CONCLUSION AND RECOMENDATIONS}

Environment has a significant negative effect on Entrepreneurship Spirit, and seen from the answers of Environmental Respondents to contribute well.

Lifestyle has a positive and significant effect on the spirit of entrepreneurship, and seen from the respondents' answers Lifestyle gives a good contribution to encourage entrepreneurial spirit

The Role of Social Media has a positive and significant effect on the Entrepreneurship Spirit and judging by the respondent's answer shows that the Millennial generation accepts the existence of Social Media

Between Environment, Lifestyle and the Role of Social Media has an influence on the Entrepreneurship Spirit. Whereas the lifestyle which has the most dominant influence on the spirit of entrepreneurship as well as Millennials contributes to the Entrepreneurial Spirit well. 


\section{Recommendations:}

- Regarding the Environment variable in the questionnaire statement "My extended family has a habit of exchanging ideas and discussing anything related to the future. Have the lowest, because it should be a more intimate family environment in discussing the entrepreneurial spirit;

- Regarding the Lifestyle variable in the statement "I have the ability to explore / explore what's in me" with the lowest value, then it is better for the Millennials to not hesitate to develop the potential that exists within themselves;

- With regard to the variable Social Media Role in the statement "I feel confident to obtain all information through social media" has the lowest value, it is better for Millennials to realize that with Media Soil it makes thinking more developed especially to increase creativity and read opportunities in creating himself to be passionate about entrepreneurship;

- Regarding the Entrepreneurship Spirit variable in the statement "I observe an increase in population income" and "I have a desire for a clearer future" to get the lowest score, then Millennials should better observe how to increase income and face the challenges of the future. front with all the efforts that can be empowered at this time;

- Suggestions for completing the results of this study are for the next researchers to increase entrepreneurial spirit is to conduct research outside the independent variables used in this study, for example government policy, social change, technological adaptation and market opportunities that can be used to enhance entrepreneurial spirit for generations Millennial, considering that there is an influence of $56.1 \%$ from other variables not included in this study, then the Millennials should remain enthusiastic in entrepreneurship to get a better life.

\section{REFERENCES}

1. Adi Yanuar Pribadi, Mashariono (2017) "Pengaruh Kualitas Pelayanan, Lokasi dan Harga terhadap Kepuasan Konsumen" dalam format jurnal, Jurnal IImu dan Riset Manajemen, volume 6 nomor 12 Desember 2017 STIESIA pdf, diakses pada 20 Juli 2018.

2. Bustami, Bernadien, Sandra Nurlela \& Ferry. 2007. Mari Membangun Usaha Mandiri: Pedoman Praktis Bagi UKM, Yogyakarta: Penerbit Graha IImu.

3. Frinces, Heflin. 2004. Kewirausahaan dan Inovasi Bisnis, Cetakan Pertama, Yogyakarta: Penerbit Darusalam. Hadiyati, E. 2010.

4. Chan-Olmsted. S. M., M. Cho., \& S. Lee. (2013). User perceptions of social media: A comparative study of perceived characteristics and user profiles by social media. Online Journal of Communication and Media Technologies 3(4): 149-177.

5. Ferdinand, A. 2014. Metode Penelitian Manajemen. Edisi Kelima. UNDIP Press. Semarang.

6. Ghozali, I. 2011. Aplikasi Analisis Multivariate Dengan Program IBM SPSS 19. Edisi Kelima. Universitas Diponegoro. Semarang.

7. 2014. Aplikasi Analisis Mulivariate Dengan Program IBM SPSS. Edisi Kelima. Universitas Diponegoro. Semarang.

8. Frdinand Augusty(2014). Metode Penelitian Manajemen, Pedoman penelitian untuk Penulisan skripsi, tesis dan disertasi ilmu manajemen. Edisi 5, penerbit:Universitas Diponegoro, Semarang.

9. Govindarajan, M. (2007). Marketing Management (Concepts, Cases, Challenges and Trends 2nd Edition). New Delhi: Prentice Hall of India Private Limited.

10. Hawkins, Del I, J, Best, Roger, dan Coney, Kenneth A. (2007). Consumer Behavior:Building Marketing Strategy. The McGraw-Hill Companies, Inc, New York.

11. Hahn, Harley. (2000). The Interest Complete Reference. Second Edition. McGraw Hill, New York.

12. Hendro, Ir. 2006 Hanbook of Entrepreneurship. Be. A Smart and Good Entrepreneurhip. Six Edition, New York: MC. Graw Hill Publishing. 
13. Husein. (2002). Metode Riset Bisnis. Jakarta: PT Gramedia Pustaka Utama.

14. Kotler, Philip dan Kevin L, Keller. (2009). Manajemen Pemasaran. Jilid 1 dan 2. Edisi 13. Terjemahan Bob Sabran. Penerbit Erlangga.

15. Kuswara Heri, Artikel berjudul "Mewujudkan "Entrepreneurial Campus adalah sebuah Keharusan terdapat pada situs: www. dikti.go.id.

16. "Pengembangan Kewirausahaan Mahasiswa" dalam http/www.technopreneurstudentwelfare.its.ac.id.

17. Retno Budi Lestari dan Trisnadi Wijaya "Pengaruh Pendidikan Kewirausahaan Terhadap Minat Berwirausaha Mahasiswa di STIE MDP, STMIK MDP, dan STIE MUSI "Forum Bisnis Dan Kewirausahaan Jurnal IImiah STIE MDP, pdf, diakses pada 20 Maret 2018.

18. Rhenald Kasali dkk. 2010, "Modul Kewirausahaan untuk Program Strata 1", Bank Mandiri dan Yayasan Rumah Perubahan: Jakarta.

19. Robert. Entrepreneurship. 6 Edition. Boston:McGraw Hill).

20. Scarborough, N.M. \& T.W. Zimmerer. 2005, Essentials of Entrepreneurship and Small Business Management, Fourth Edition, New Jersey: Prentice-Hall.

21. Sugiyono. 2010. Metode Penilitian Bisnis. Edisi Dua Belas. Cetakan ke Tujuh Belas. ALFABETA. Bandung.

22. 2012. Metode Penelitian Kuantitatif Kualitatif dan R dan D. AlfabetaBandung.

23. 2014. Statistika Untuk Penelitian. Alfabeta. Bandung.

24. Suryana. 2003. Kewirausahaan, Pedoman Praktis, Kiat dan Proses Menunju Sukses, Edisi Revisi, Jakarta: Salemba Empat. 